\title{
Politeness Strategies Employed by Chuka University Students in their Social Media Discourse
}

\author{
Miriti Gervasio*, Dr. Humphrey, K. Ireri \\ Chuka University, P.O Box 109, 60400, Chuka Kenya
}

*Corresponding Author: Miriti Gervasio, Chuka University, P.o Box 109 60400, Chuka Kenya

\begin{abstract}
This article sheds light on the politeness strategies employed by Chuka University students in their social media discourse using WhatsApp interaction platform. The four broad categories of politeness strategies (Positive politeness, Negative politeness, Bald on record and Off-record strategies) as spelt by Brown and Levison in their Politeness Theory were analysed using the data collected from the university students conversations via their WhatsApp platforms. This study employed a qualitative research technique and a descriptive research design. It utilized the snowball and purposive sampling procedures. Upon the collection of the data, content analysis was done in order to analyse the politeness strategies inherent in the discourse. The study revealed that university students strive to maintain cordial relationships by use of positive politeness, and they normally avoid imposing on each other by use of negative politeness strategies. Sometimes students use Off-record strategies in order to avoid being accused of committing a Face Threatening Act (FTA), which is likely to ruin their relationships.
\end{abstract}

Keywords: politeness strategies, Face Threatening act, social media discourse, quality face, and social identity face.

Abbreviations: T-text, FTA-Face Threatening Act, H-Hearer, S-Speaker

\section{INTRODUCTION}

People interact with one another on a daily basis using different media such as face to face and social media. One of the ways of maintaining cordial relationships among the interactants is by devising mechanisms that warrant politeness in their communication. This paper sheds light on the politeness strategies employed by Chuka university students in their social media conversations via WhatsApp interaction platform. The study utilises the four categories of politeness (positive politeness, negative politeness, Bald on record, and Off-Record strategies) as postulated by Brown and Levinson (1987). Brown and Levinson (1987) argue that there are universal principles that underlie the construction of politeness. This introduces a new perspective to politeness by drawing attention to the similarities involved in the construction of polite utterances across differing languages and cultures. The similarities noted are of two types; how polite utterances are constructed linguistically, and how the polite expression of utterances is modified depending on the social characteristics of the interlocutors and the situations they are in.

Politeness provides a resource upon which participants may use to manage relationships. Participants are normally concerned with managing the face and sociality rights. The face has two interrelated aspects; quality and social identity face. The two are related to Brown and Levinson positive face in that it refers to the need that individuals have to be evaluated positively. 'Quality face' is the desire to be judged positively in terms of personal qualities and 'social identity face' is the desire to be acknowledged in our social identity roles, (for example, as a teacher, wife or son) thus accounting for the public element neglected in Brown and Levinson interpretation of the face (Spencer -Oatey, 2000). The current study focused on the mechanisms used by students to maintain each other's face in the process of interacting via social media platforms. It investigated how politeness strategies are envisaged in student's conversations. This study also looked into the ways in which university students-maintained relationship and their quality face and social identity face in the process of communication, which is an indicator of positive politeness. It was discovered that students showed solidarity which an indicator of positive politeness in an endeavour to maintain each other's face 
Park (2008) argues that in order to understand the manifestation of on-line social interaction and to enhance fruitful interaction and collaboration through the CMC channel, analysis of patterns of sociointerpersonal communication among on-line discourse is vital. Drawing focus on people with arthritis, Harrison and Barlow (2009) explore the use of politeness strategies in an on-line self- management program. The results reveal that the participants used indirect suggestions and positive politeness to express their experiences and problems. On the other hand, Li (2012) conducts a study to analyse the discourse by Chinese learners in the EFL context. The results showed that participants used positive, negative, and bald on record strategies to foster an atmosphere of friendship and solidarity. This study specifically used WhatsApp to analyse and explore the four categories of politeness strategies employed by university students as they interacted via WhatsApp. It was discovered that many are times when students strive to remain polite by making use of the politeness strategies in their social media discourse.

Using naturally occurring data from Twitter corpora, Sifianon (2015) studies the manner in which politeness is conceptualized in the online context. The researcher finds that new media affects the use of politeness strategies. On the other hand, Izadi and Zilaie (2012) examine the use of politeness strategies in exchanges of email. The participants were close friends, and the researcher used 60 emails. Since the participants were close friends, the researcher analysed the data in terms of constituent positive politeness strategies that enhanced the ways of intercultural computer mediated communication. This study did not use the email or Twitter as the medium, but WhatsApp texts were used in analysing the various types of politeness strategies employed by students. The findings revealed that the four types of politeness strategies(positive politeness, negative politeness, bald on record, and off- record)were used.

Luzon (2013) studies the use of (im)politeness strategies in an academic blog discussion, revealing a high frequency of the strategies used to deter conflict. On the other hand, Chejnova (2014) studies the manifestation of impoliteness in email communication analysing means of expressing politeness, degrees of directness, and amounts of lexical and external modifications. The findings reveal that respondents used both positive and negative strategies in conveying their meaning. Similarly, Park (2008) investigates linguistic politeness in CMC. The analysis of real time on line discussion of participants of the study demonstrated that politeness strategies are used for interpersonal communication. This study also found out that students use positive and negative politeness strategies in order to maintain a cordial relationship or 'comradeship' among themselves.

Humour characterizes social media discourse. In this study, jokes/ humour is treated as one of the positive politeness strategies. There has been an argument that social media discourse, especially the e-chats,is laced with jokes. Danet (1995) in Georgakopoulou(1997) observes that the use of playfulness, humour, and wit is fairly finding, even if controversial in its interpretation. They also note that synchronous types of CMC, such as e-chat, have been found to be strikingly playful and resembling real life forms of play like charades having a masked ball or a carnival, hosting a party, and putting on a show. This study found that humour is depicted in social media discourse in a peculiar manner. This study discusses the politeness strategies, inherent in students social media.

\section{Methodology}

This study employed a qualitative research technique and a descriptive research design. It utilized the snowball and purposive sampling procedures. Snowballing was used to identify the WhatsApp groups from which the texts were extracted. Before data collection commenced, the researcher was added to the WhatsApp groups by the various students' group administrators upon request. The study utilized qualitative methods to analyse data. The process began by extracting the texts that illustrated the politeness strategies used by university students. The texts extracted from WhatsApp groups were then categorized according to the four categories of politeness as postulated by Brown and Levinson (1987). After categorizing the data collected, content analysis was done in order to give a detailed account of politeness strategies exhibited by university students in their discourse.

\section{DISCUSSION}

\subsection{Positive Politeness Strategies}

Positive politeness is a redress directed to the addressee's positive face, his/her perennial desire that his/her wants (or the actions/acquisition/values resulting from them) should be thought as desirable 
(Brown and Levinson1987). Positive politeness strategies are realized through a number of devices that are discussed below.

\subsubsection{Noticing and Attending to the Hearer's(H) Interests, Wants, Needs or Goods}

This strategy suggests that speaker(S) should take notice of aspects of H's condition like noticeable changes, remarkable possessions, anything which looks as though $\mathrm{H}$ would want $\mathrm{S}$ to notice and approve it.

In this strategy, the S can make a general comment on H's state. Consider the following example.

\section{T1}

\section{A: comrades I am humbly requesting for your votes}

(Comrades I am humbly requesting for your votes)

B: Kevoo u have always been smart both physically and mentally, count my vote come rain come sunshine

(Kevoo, you have always been smart both physically and mentally, count my vote come rain come sunshine)

The student $\mathrm{B}$ attends to the interest of student $\mathrm{A}$, who is vying and promises him his vote. By promising him his vote, the needs and the interests of the candidate are catered for hence positive politeness. Student B takes notice of the Student A and gives his approval hence making him feel good. This helps students to build and maintain relationships.

\subsubsection{Intensifying Interest to H as a Strategy}

This is another strategy for $\mathrm{S}$ to communicate to $\mathrm{H}$ that he shares some of his wants by intensifying his/ her interest and his own (S's) contributions to the conversations, by 'making a good story.' This couldbe done with the purpose of pulling $\mathrm{H}$ right tothe middle of the events being discussed. The following example can serve to illustrate the two strategies mentioned above.

T2

A: Ebututoekumikilamtutupee John coz ingekuwa mm hamgekuwamnaatendclss

(Let's contribute kshs 10 and give it to John because if it were me, you would not be attending classes.)

\section{B: Ndiomaanahukuitishahiyokazi}

(That's why you did not ask for such duties.)

\section{A1: Singewezananajijua. I tried class rep hadi nikachoka...I luv John he} always sacrifices for us especially me...thanks, John

(I know myself I could not manage. I tried class representative, and I was not able... I love John; he always sacrifices for us especially me.)

In the above example, student A and A1 exaggerate approval of John by even suggesting that each group member to contribute ten shillings to appreciate him for the work he has done as a class representative. The student also points out that she could not have performed the way John is performing because she was once a class representative, and she was unable to do a good job. This is meant to intensify the interest of $\mathrm{H}$, which also increases his intrinsic interest in him.

\subsubsection{Use of Humour/Jokes as a Strategy}

Jokes usually rely on mutually shared values and background knowledge; meaning they can be used to stress that shared background and values. Joking as a technique of positive politeness technique is used to put $\mathrm{H}$ at ease. Jokes may be used as a strategy that exploits politeness and attempts to redefine the size of the FTA. Students' conversations are characterized by humorous episodes, as evidenced in the following texts. 


\section{T3}

A: Hey guys, kuulizatu.Ukiwana aunt anapenda kutravel utamuita safari aunt?

(Hey guys,just asking,if you have an aunt who loves travelling would you call her safari ant?)

B: Hahaha!! Exactly

C: Wewe ni kondoo sana

(You are so stupid)

\section{A2: Wach amatusi wewe}

(Stop being abusive)

D:Lakini mbona ukiita mtu kondoo anajam sana.Tumekuwa tukiitwa kondoo kwa Bible nahataukiwa mtoto hapo Sunday school ulikuwa unajiita kwa ile wimbo ya "ingia ingia uwe mmoja wa kondoo"

(Why is it that when you call a person a sheep, they get mad, yet we are often referred to as sheep in the bible, and when we were young we would often sing in the Sunday school saying, "enter enter and be one of the sheep",)

B2: Hehehe hiyo ni ukweli

(Hehehe, that's true)

A3:Kondoo ni wewe ni kondoo basi

(You are the foolish one then)

In the above examples, students refer to one another, the church and the politicians in avery humorous way. In the conversation, student C insults the other by calling him/her "kondoo" (sheep) and proceeds to justify why "kondoo" (sheep) is not an insult as it is used in the church to refer to the faithful. The word sheep is used with a positive connotation in the bible as it symbolizes the humble or the meek, but outside the church, the word is associated with foolishness hence used offensively.

Sometimes university students also use word play for lacing their contributions with humour.Consider the following examples.

\section{T4}

A: Someone to wake me up we go for the hike

(Someone to wake me up as we go for the hike)

B: Wee endelea na usingizi yako..... people are building the nation utacome kupaka rangi.......

(You continue sleeping.... people are building the nation....... you will come to paint it.)

In the above example, the wordplay is achieved through the use of the word 'building the nation.' Literally, building the nation has nothing to do with putting up a house, but the word has been used to mean so, and student $\mathrm{A}$ is told by $\mathrm{B}$ that now that people are building the nation, and he is there sleeping, he will do the manual work of painting it. Consider another example below where word play has been used. This ismeant to make the people in the group laugh, and it also breaks the monotony of sending chats that communicate only serious issues. The following example exploits the sound features of the word 'kiss' and "Kisii" (an ethnic community in Kenya) to create humour.

\section{T5}

A. Jana nilikuwa maji sana leo nafungu anipate updates Napata texts za kiss (Kisii) kila mahari

(Yesterday I was drunk, today I open the WhatsApp to get updates, only to get texts written in Ekegusii) 


\section{B: Kiss na kila mtu hii group si Kisii ... atammezidi.}

(Kiss with everybody, (Kisii meaning Ekegusii language) and everyone is not a Kisii,... you have become too much)

In the above example, students make fun out of the word Kisii.It had happened that the students from the Kisii community had switched to their mother tongue (Ekegusi) and by the time student 'A' open his whatsApp group, he finds conversations written in Ekegusii. The fun comes out of the word "Kisii" and 'kiss' that the student deliberately uses them interchangeably. Student A and B use humour to show their displeasure with students from the Kisii community who had turned into their mother tongue, excluding others who come from other communities. Since the criticism is made on a light note, nobody is likely to be offended.

\subsubsection{Use of In Group Identity Markers}

Although In Group Identity markers were discussed in our previous chapter, it is still discussed here as it is one of the strategies of positive politeness. By using, any of the many ways to convey in-group membership, $\mathrm{S}$ can implicitly claim the common ground with $\mathrm{H}$ that is carried by that definition of the group.These include in-group usages of address forms of language or dialect,slang or jargon and ellipsis. Forms that are used to convey in-group membership include generic names and terms of address such as, 'pal', 'dear', 'duckie', 'buddy', 'honey', 'Iuv', 'blondie', 'mom', 'babe', 'brother', 'guys', 'fellas', 'sweetheart', 'sister'and'cutie'. These forms can be used to soften FTAs. Consider the following;

T6

A: night poa siz....

(Good night sister)

B: $u 2$ bro

(You too bro)

C: pamoja

(Together)

D: pamoja pals

(Together friends)

\section{T 7}

A: Nakwambia wasee wamengangana na reprts ata hawapatikani

(I tell you that students are struggling with report writing; therefore,they are not available)

$\mathrm{B}$; The largest proportion ya skills zenye wasee wa BSC Agric watatokanayo Chuka ni report writing.

(The largest proportion of skills that BSC (Bachelor of Science) Agriculture students will get from Chuka University is report writing)

T8

A: Kakenya usisahau iyo kakitu joh

(Kakenya please don't forget that thing)

B: beb what is it??? Don't say u $r$ still preparing supper till now. Baby

(Baby what is the problem?Don't say you are still preparing supper until now)

A2: nakula bae

(I am eating baby)

The students use endearing terms such as 'baby' which over time has changed to "beb" then " $b b y$ ", then 'babe' and finally "bae" as well as 'sweetheart' which has several variants such as "sweetie", "swry”, "swirie", “swt@” and "swee”. Other terms commonly used are 'bro,' for brother, 'siz' for 
sister, "brathee" or "braza" for brother, while'guys," "wasee" and "pals" are general terms used by students to refer to one another. The use of these words shows that students have close a relationship among themselves and use such forms when requesting for something or when showing intimacy.

\subsubsection{Offering and Promising as Strategies}

Offering and promising are considered the natural outcome of choosing this strategy even if the promises or offers are false. Students make use of this strategy in their social media discourse. Consider the following examples.

\section{T9}

A: Kim count on my support next year, tutakuwa nawe hadi kwa debe.

(Kim, I assure you my support next year. I will be with you all the way to the ballot box)

\section{B:Thanks.}

In the above example, student A promises to support another student who would be vying the following year for one of the student leaders' position. This is geared towards making him feel good hence positive politeness.

\subsubsection{Inclusion of both $S$ and $H$ in the Activity}

This strategy is achieved with the use of 'we' pronoun form when S literally means 'you' or 'me'. The word 'let's which in English is inclusive for 'we', can also be used in realizing this strategy. Below is an example;

\section{T10}

A:Guys, let's plan for hike... or what do you see?

(Guys let us plan for the hike...or what do you think?)

B:I second

(I second)

C:Good idea

(It is a good idea)

Student A uses the word 'let's in order to involve others in the planning of an outing. By so doing, the H's face is not threatened. This is a sign of positive politeness. It also implies that students strive to remain cordial by uniting in accomplishing a mission.

\subsection{Negative Politeness Strategies}

Negative politeness is a redressive action directed to the addressee's negative face: his want to have his freedom of action unhindered and his attention unimpeded. Negative politeness is realized through a number of devices that are discussed below in light of the politeness theory.

\subsubsection{Apologizing as a Strategy}

This is when the speaker begs for forgiveness from the hearer by using apologetic words such as "sorry, "and I apologize.

\section{T11}

A: Hey guys, I am sorry lec hatamak eleo

(Hey guys, I am sorry, our lecturer will not attend today.)

B: what!! Mbona hakutushow mapema??

(What! Why did he not notify us earlier?)

A2:Oh sorry guys the information came late

C: hatugharamie hiyo loss yote @ least kafare

(He should at least cater for our bus fare) 
A3:I really apologize guys and na promise next time will communicate mapema

(I really apologize and I promise that next time it will be communicated early.)

D: ok then!!

(Okay, then)

A4: Thanks for understanding.

(Thanks for understanding)

The speaker in the conversation is using words like 'sorry,' and 'I apologize' to beg for forgiveness from the hearer because of late communication. By doing this, the speaker minimizes the face threatening acts through an apology. This implies that students mend fences in order to show politeness hence, maintaining cordial relationships.

\subsubsection{The Strategy of being Conventionally Indirect}

This strategy involves the speaker facingopposing tensions: the desire to give, to be indirect and at the same time being on the record.

\section{T12}

A: Hey guys, we could be meeting for our2morrow's class@ $@$ 7.or9a.m

(Hey guys we could be meeting for tomorrow's lecture at 7.00 am or 9.00 am)

\section{B: NKT!!! Kwani hauko sure fala hii?}

(Nkt!!! Are you not sure you fool?)

C: Kwenda uko!!!

(Nonsense)

A: Luk guys! The lec has just communicated

(Look guys! the lecture has just communicated)

B: Aiii

C: please, would you show him amalize unit leo.,

(Please, would you inform him to complete the unit today?)

A: Ok guys will discuss that. Thank you

(Okay guys we will discuss that. Thank you)

The conventionally indirect strategy is indicated by words like 'could, 'please, and 'would' as evident in $\mathrm{C}$. the use of such words by the students is meant to minimize the imposition and maintain their cordial relationship.

\subsubsection{Minimizing Imposition, and Incurring as Debt Strategies}

$\mathrm{S}$ can achieve negative politeness through the use of words that do not coerce the $\mathrm{H}$ into doing something but by asking indirectly. S may, for instance, use a word like borrow instead of word ask. Therefore, this reduces the imposition. Similarly, in incurring a debt S can address an FTA by explicitly claiming his indebtness to $\mathrm{H}$ as in the following;

\section{T13}

A: Hey Brayo!Will appreciate if you perform your new song at the function.

(Hey Brayo! we will appreciate if you perform your new song at the function)

B: Mmmm; No, I'm not in the mood.

(Mmmm, No I am not in the mood.) 


\section{C: Hey bana popularize your new song}

(Hey Sir,make your song popular)

D: Btw this is an avenue kuwa fame.

(By the way this is an opportunity to become famous)

B: Anyway can't repay you guys for your support will try.

(Anyway,I cannot repay you guys for your support. I will try.)

A: Thanks Brayo I will cheer you

(Thanks Brayo, I will cheer you)

B: Thanks!!!

\section{T14}

A: Swee, can I have a bite of that delicious birthday cake.

(Sweetheart, can I have a bite of that delicious birthday cake?)

B: Ur welcome my dia.

(You are welcome, my dear.)

The strategy of minimizing incurring debt is realized by the use of phrases like "will appreciate 'can't repay you for your great support' this shows that the speakers attempt to incur the debt hence minimizing the imposition to the hearer. In an example, $2 \mathrm{~A}$ tries to minimize the imposition by the use of the expression 'can I have a bite.' Incurring debt is a demonstration that students strive not to impose on others, which is a means of depicting politeness as they interact.

\subsubsection{Stating the Face Threatening Acts (FTA) as a General Rule}

This is a strategy whereby $\mathrm{S}$ and $\mathrm{H}$ are dissociated from a particular imposition in the FTA, and therefore ones end up saying that $\mathrm{S}$ does not impinge on $\mathrm{H}$ but is merely forced by circumstances to state the FTA since he/she is obliged or it is a general social rule.

\section{T15}

A: I am going to remove those using their local languages from this group. This group is meant for each of us

(I am going to remove those using their local languages from this group. This group is meant for each and every one of us)

B: Guys lets respect one another

(Guys, let us respect one another)

A: Mamboz msee

(How are you?)

B1: ehe,sema

(Yes, tell me something)

Al: wewe, utaacha maringo mingi

(You will have to minimize your pride)

$C$ : We nawe nyamaza

(Can you shut up?)

B2: usiniletee ujinga bana

(I don't want your nonsense)

A2: Kwani unafikiria wewe ni nani

(Who do you think you are?)

B:unajifeel sana, sindio?

(You value yourself so much, don't you?) 
In the above conversation, the group administrator is forced to inform the other interactants that they are supposed to respect one another by using a language that is understood by each one of them and avoid their local languages failure to which they risk being removed from the group. The group administrator is obliged to state the FTA for the interest of the majority of members who could not understand the Ekegusii language that a section of members had switched to. This may not be polite to those using the Ekegusii language, but it is quite in order for the majority of the members.

\subsection{Bald on Record}

Bald on Record is a politeness strategy that is viewed in light of Grice's Maxims (Grice, 1975), that is, speaking in conformity with the four maxims that include :quality, relevance, quantity and manner maxims. The four maxims are discussed to show how this kind of politeness is realized.

\subsubsection{Use of Maxim of Quality}

This maxim requires one to be non spurious (speaking the truth and being honest) and avoiding saying that which you believe is false. This maxim is illustrated in the following interaction;

\section{T16}

\section{A. Hey mtu aezi expect smthng from $u$}

(Can someone expect anything from you?)

\section{B. No noooo leo kila mtu $n$ kupambana n ahali yake}

(No, everyone should deal with their own situations)

Interactant A wants something from another interactant. It is, however, clear that interact A's wish is declined by the other interactant who candidly tells him/her that every person should face his/her own challenges. This demonstrates the candid nature of students when it comes to some issues.

\subsubsection{Maxim of Manner}

The Maxim of manner proposes that an interactant should be brief, clear, and orderly.

\section{T17}

\section{A: Practical iko wapi guys?}

(Where is the venue for the practical?)

\section{B: Pra ciko sides ya secondary, na iko kesho 9:00 a.m}

(Practical will be tomorrow around the secondary school (Ndagani Secondary School), and it will be at 9.00am)

\section{A: Ok dude}

(Okay man)

$$
B^{l} \text { : Karibu!!! }
$$

(Welcome)

Interactant $\mathrm{A}$ inquires whether there would be a practical class and he is given a clear response by Band in an orderly manner. This implies that students observe clarity when communicating information related to their core business at the university; academics.

\subsection{Off -Record Strategies}

When communication is done off- record, it is done in a way that it is impossible to attribute only one clear communicative intention to the act. The hearer can interpret and give the message more than one meaning. Thestrategy utilizes language indirectly and employs a number of devices explained below.

\subsubsection{Over-Generalization as a Strategy}

It is an off-record strategy whereby the speaker does not name the hearer who is addressing him/her directly. It involves making statements or drawing conclusions that are based on too few facts or a small number of instances. 


\section{T18}

A: These Gikuyu men surprise me

(These Gikuyu men surprise me)

B: What have they done?

(What have they done?)

C: A Gikuyu man will finish his wedding by 3:30p.m and still open a shop by 4:00p.m

(A Gikuyu man will finish his wedding by 3:30p.m and still open a shop by 4:00p.m)

D: Hehehe!!! Hii pesa itawamaliza

(Hehehe this money will ruin them)

In the conversation, the speaker is drawing conclusion on a community that is "Gikuyu" to show how they love money to the extent that immediately after their wedding ceremony, they willopen their businesses and life goes on normally as opposed to the expectation that they should enjoy the celebration, later proceed on to honeymoon among others after marriage. Another example is where some students who exhibit inappropriate behaviour are castigated through over generalization. Consider the following example;

\section{T19}

A: Kuna watu apa mnafaa kupewa fee yenu yote mrudi nyumbani till you mature to be admitted back.

(There are some people here who need to be refunded all their fees they paid, they go back home and come back to be readmitted when they mature)

\section{B:Nini}

(What?)

Student A does not mention anybody in particular but has over-generalized so as not to be on record for having criticized anybody in particular.

\subsubsection{Using Rhetorical Questions as a Strategy}

This is an off-record strategy in which a speech or writing intended to be effective, persuasive, and influence people is not honest.

T20

\section{A: Hey lakini madam mnapeda pesa sana!}

(Hey, but ladies have high affinity for money)

\section{B: Eish! hakuna mtu hapendi pesa. Kwani wewe hupendi?}

(Eish! Everyone loves money. Don't you love it yourself?)

C: Yao ni excess sana

(Theirs is much more)

D: Wanaume mtashida to hapa eti wanawake wanapenda pesa,, Judas wa bible alikuwa bibi ya nani?

(Men always think women have more affinity for money but whosewife was Judas of the Bible?

\section{T21}

A: Hakuna Cat hadi Monday.....

(There is no Continuous Assessment Test until Monday...) 
B: Man uko sure na hii wewe...should we quit revising till next week??? Or what do you want to suggest?

(Man, are you sure about this... should we quit revising till next week ? Or what do you suggest?)

In the above examples, rhetorical questions are used as an Off- record strategy by student D in T20. She asks whose wife was Judas of the Bible? If it is true that it is only women who have a high affinity for money than men. Judas is said to have betrayed Jesus after receiving some money despite being one of the disciples. In the same text, student B asks Student A rhetorically if there is anyone who does not love money. In T21, student B rhetorically asks whether they should stop revising for the Continuous Assessment Test now that it has been postponed. By using rhetorical questions, the students are able to persuade one another on how they should perceive things; that is, in a manner whichis not acrimonious as they do not ask a question directly as this would be tantamount to committing an FTA.

\subsubsection{Use of Incomplete Statements and Ellipsis as a Strategy}

Use of incomplete statements and ellipsis is a common phenomenon. Students use this strategy often so as not to be on record for hurting a colleague. A good example is provided in T11 whereby student $\mathrm{C}$ responds, 'uuui....heheee.' The following is also a good example of ellipsis;

\section{T22}

A: Jokes aside pliz ...others gonna miss that CAT.......y mislead people surely

(Let's put jokes aside please.... some of the student are likely to miss the Continuous Assessment)

B: Exactly.

Student A's statement was in response to another student who was making fun as to when the Continuous Assessment Test would be done and by using ellipsis, he avoids saying his real feelings about what he felt about that behaviour. This is an Off-record strategy that helps to maintain relationships among the students.

\section{CONCLUSiON}

Students use various politeness strategies which are evident in the social media discourse. These strategies enable them to build and maintain a relationship among themselves. Positive politeness like the use of humour and jokes make the students be in the light mood and lessen the seriousness of life at the university due to the challenges encountered. Students strive as much as possible not to threaten the H's face through the use of several devices that realize positive politeness. Similarly, students attempt not to impose or impinge on the hearer by making use of the negative politeness strategies such as hedging and indirect requests. Sometimes students use Bald on Record where they make use of the Gricean maxims. This is when they say things exactly the way it is expected of them. Other times, students go Off-Record so as to commit an FTA. Off-Record strategies are meant to give statements whose meanings can be interpreted in more than one way; hence, one cannot be quoted or be on record for committing an FTA.

\section{REFERENCES}

[1] Bilbow, G. (1997).Spoken discourse in the multicultural work place in Hong Kong: Applying A Model of Discourse As Impression Management'. In F.Bargiela-Chiappin\&S. Harris(eds). The language of the business (Pp 21-28). Edinburgh: Edinburgh University Press.

[2] Brown, P and Levinson, S. (1987).Politeness: some universals in language usage. UK: CUP.

[3] Chejnova, P. (2014). Expressing politeness in the institutional E-mail communication of university students in the Czech Republic. Journal of Pragmatics, 60 (1), 175-192.

[4] Danet, B. \& Herring, S. (2007). Introduction: Welcome to multilingual internetlanguage. In Denet,B and Herring, S (Eds). The multilingual Internet: Language, culture and communication online(3-39). Oxford, UK: Oxford University.

[5] Danet, B (1995) playful expressivity and artifulness in computer mediatedcommunication 1 (2) retrievable from https:// cloi org/10.vii//.1083-6105. 1995.t boo 323.x 
[6] Georgokopoulou, A. (1997).Discorse analysis: An introduction. Britain: Edinburgh University Press.

[7] Izadi, A. \&Zilaie, F. (2012). Politeness strategies in Email exchange in Persian. Journal of Comparative Literature and Culture, 2 (1), 86-90.

[8] Li, M. (2012). Politeness strategies in Wiki- Mediated communication of EFL collaborative writing tasks. ALLT Journal,42 (2), 1-26.

[9] Luzon, M, J. (2013). This is an erroneous argument: Conflict in Academic blog discussions. Discourse Context and Media, 2 (3), 111-119

[10] Park, J., R. (2008). Linguistic politeness and face work in Computer Mediated Communication, Part 2 An Application of the Theoretical Framework.Journal of the American Society of Information and Technology, 59 (14), 2199-2209.

[11] Sifianou, M. (2015). Conceptualizing politeness in Greek.evidence from twitter corpora. Journal of Pragmatic advance. Online publication.http://dx.do:org/10.1016/j.pragma.2015.05.019

[12] Spencer Oately, H. (ed) (2000).Culturally speaking: London:Continuum

Citation: Miriti Gervasio, Dr. Humphrey, K. Ireri. Politeness Strategies Employed by Chuka University Students in their Social Media Discourse. "International Journal on Studies in English Language and Literature (IJSELL), vol 7, no.89, 2019, pp. 53-64. doi: http://dx.doi.org/10.20431/2347-3134.0708006.

Copyright: (C) 2019 Authors. This is an open-access article distributed under the terms of the Creative Commons Attribution License, which permits unrestricted use, distribution, and reproduction in any medium, provided the original author and source are credited. 